Original Article

\title{
Agents causing genital infections in routine cytological tests: frequency and characteristics of Papanicolaou smears
}

\author{
Agentes causadores de infecções genitais em exames citológicos de rotina: frequência \\ e características dos esfregaços de papanicolaou
}

\author{
F. S. Carvalho ${ }^{1}$ (D), N. K. A. Porto ${ }^{2}$ (), P. V. M. Azevedo ${ }^{1}$ (), P. K. A. Magalhães ${ }^{1}$ (), E. N. de Araújo $^{1}$ (D), M. S. Correia ${ }^{1}$ (D),

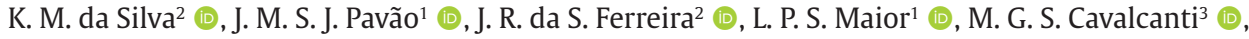 \\ G. C. Ferreira-Júnior ${ }^{4}$ (D) and T. J. Matos-Rocha ${ }^{1,2}$ (D) \\ ${ }^{1}$ Centro Universitário Cesmac, Maceió, AL, Brasil. \\ ${ }^{2}$ Universidade Estadual de Ciências da Saúde de Alagoas, Maceió, AL, Brasil. \\ ${ }^{3}$ Universidade Federal da Paraíba, João Pessoa, PB, Brasil. \\ ${ }^{4}$ Instituto Federal de Educação, Ciência e Tecnologia do Acre - IFAC, Xapuri, AC, Brasil.
}

\begin{abstract}
Urinary tract infections are responsible for most human infections, these are caused by bacteria, fungi, protozoa and associated microorganisms. The goal of this study was to determine the rate of vaginal infection-causing agents in routine cytological exams and also to evaluate the characteristics of positive tested Pap smears. A retrospective documental with descriptive aspect research was performed in a Clinical Pathology laboratory from Maceió-AL. The results of the Pap smears exams for Trichomonas vaginalis, Gardnerella vaginalis, Candida spp and HPV were arranged in a database as well as other data such as bacterial, protozoan, fungal and viral coinfections. The sample was composed by 18.645 women who have undergone Pap smear exams from 2013 to 2017. Of these analyzed exams, 27.4\% in 2013, 10.9\% in 2014, 10.6\% in 2015, 15.2\% in 2016 and 13.67\% in 2017 were within normal range, however more than half of these exams presented some infections caused by unspecific or microbiological agents. By analyzing all the reports, $4.073(21.84 \%)$ presented inflammations caused by some species of infectious agent with the following rate order: G. vaginalis and T. vaginalis. Furthermore, it was possible to confirm high rates of coinfection by and Candida spp. The rate of genital infections in this study highlights that there is a public health matter that must be controlled, which points a greater need for monitoring, guidance and actions towards greater awareness in order to prevent these problems.
\end{abstract}

Keywords: Trichomonas vaginalis. Gardnerella vaginalis, Candida spp., Papa Nicolau Exam.

\begin{abstract}
Resumo
Infecções do trato urinário são responsáveis pela maior parte das infecções humanas, sendo causadas por bactérias, fungos, protozoários, e por microrganismos associados. $\mathrm{O}$ objetivo deste trabalho foi determinar a frequência de agentes causadores de infecções vaginais nos exames citológicos de rotina, bem como avaliar as características dos esfregaços positivos. Foi realizada uma pesquisa do tipo documental retrospectiva de aspecto descritivo, com abordagem quantitativa, em um Laboratório de Patologia Clínica de Maceió-AL. Nesse sentido, os resultados dos exames colpocitológicos para Trichomonas vaginalis, Gardnerella vaginalis, Candida spp e HPV foram organizados em um banco de dados, contendo os resultados para estes agentes, bem como a coinfecção bacteriana, protozoária, fúngica e viral. A amostra foi composta por 18.645 mulheres que realizaram exame colpocitológico, no período de 2013 a 2017. Destes exames analisados 27,4\% em 2013, 10,9\% em 2014, 10,6\% em 2015, 15,2\% em 2016 e 13,67\% em 2017, estavam dentro do limite da normalidade, porém mais que a metade desses exames analisados apresentou algumas infecções causadas por agentes inespecíficos ou microbiológicos. Do total de laudos analisados, 4.073 (21,84\%), apresentaram inflamações causadas por algum tipo de agente infeccioso, com a seguinte ordem de frequência: G. vaginalis, e T. vaginalis. Além disto, foi possível confirmar a elevada frequência de coinfecção entre G. vaginalis e Candida spp. Os índices de infecções genitais nesse trabalho mostram que há um problema de saúde pública que deve ser controlado, apontando uma necessidade maior de acompanhamento, orientações e de ações para uma maior conscientização para prevenir esses problemas.
\end{abstract}

Palavras-chave: Trichomonas vaginalis, Gardnerella vaginalis, Candida spp., Exame de Papanicolau.

*e-mail: tmatosrocha@cesmac.edu.br

Received: 17 May, 2020 - Accepted: 28 October, 2020 


\section{Introduction}

The urinary tract is the second most common human infection occurring site, the first being the respiratory tract (Lacerda et al., 2015). Among reproductive tract infections, vulvovaginitis and vaginosis are noteworthy and occurs when the physiological vaginal environment, composed primarily of Lactobacillus, is altered, thus allowing the proliferation of other microorganisms, and may be associated with inflammatory conditions (vaginitis) or vaginoses, which shows no evidence of inflammation (Linhares et al., 2018).

The normal vaginal microbiota is formed by several aerobic, anaerobic and facultative bacteria, being highlighted in the literature as an important protective factor against pathogens in the genital tract, and carries important reproductive function defense mechanisms, as it prevents multiplication of pathogenic microorganisms (Klebanoff and Coombs, 1991; Resende et al., 2019). Modifications in the vaginal microbiota can cause cervicovaginal infections accompanied by an abundant, homogeneous, grayish white, non-purulent vaginal discharge, with an extremely unpleasant odor, known as bacterial vaginoses (Gallo and Fabião, 2016).

Vulvovaginitis are some of the most common gynecological issues that affect women's health, affecting vaginal walls causing itching, variations in local $\mathrm{pH}$, sometimes secretions and vaginal discharge, which are the main factor that leads women to seek a gynecologist (Greenbaum et al., 2019). Urinary tract infections are caused by bacteria (bacterial vaginosis), fungi (fungal vulvovaginitis), protozoa (trichomoniasis), and by associated microorganisms (mixed vulvovaginitis) (Silva et al., 2014a). These inflammatory processes affect between $15 \%$ and $20 \%$ American women (Raugust and Duarte, 2013).

In bacterial vaginosis the most frequently associated species are Gardnerella, Atopobium, Prevotella, Megasphaera, Leptotrichia, sneatia, Bifidobacterium, Dialister, Clostridium and Mycoplasmas, although there are variations among women (Nasioudis et al., 2017). Candidiasis is characterized by a vaginal inflammatory process caused by the proliferation of fungi in the vaginal environment that leads to the appearance of symptoms (discharge, itching, dysuria, dyspareunia). Candida albicans is the most frequent agent (85\% to $95 \%$ of cases) associated with candidiasis, and in approximately $10 \%$ of cases other Candida species are found ( $C$. glabrata, C. tropicalis, $C$. parapsilosis and C. guilliermondii). When there are four or more episodes confirmed clinically and laboratorially in a 12-month period, candidiasis is called recurrent vaginal candidiasis (Ledger and Witkin, 2016; Linhares et al., 2018)

Trichomonas vaginalis is the etiological agent of trichomoniasis, being responsible for the most common non-viral sexually transmitted infection (STI) in the world (Xavier et al., 2019). Although it is sexually transmitted, it can also be transmitted through infected toilet seats. Trichomoniasis affects most women on reproductive age worldwide, with more than 170 million new cases / year worldwide, among STIs. Asymptomatic infection is the most common form, but multiple symptoms and pathologies can appear in both women and men, including vaginitis, urethritis and prostatitis. The Ministry of Health's National STI and AIDS Program, in a large national study, estimated an incidence of trichomoniasis of $8.2 \%$ in women and $1.9 \%$ in men, with the emergence of more than 4.3 million new cases per year (Mosca and Mendonça, 2016; Nievas et al., 2018).

The diagnosis of vulvovaginitis and bacterial vaginosis can be performed by several tests. In cases of bacterial vaginosis, the diagnosis includes clinical manifestations and fresh examination of vaginal secretion to identify clue cells, pH assessment and odor test (Amsel et al., 1983). The fresh examination of the vaginal content is also used to identify fungi and Trichomonas (Camargo et al., 2015). Molecular tests can be applied for the diagnosis of bacterial vaginosis, candidiasis and trichomoniasis (Lowe et al., 2009; Cartwright et al., 2013), and the culture of vaginal secretion is used to identify fungi and protozoa, considered the gold standard for detecting trichomoniasis (Machado and Souza, 2012; Lima et al., 2017). The process of vaginal secretion culture has some limitations when compared to other tests, as it has a higher cost of performance and the high growth time of the parasite in the Diamond culture, that lasts up to 7 days, in addition to the occurrence of culture contamination by bacteria of female vaginal microbiota (Ferraz et al., 2014; Lima et al., 2017)

Although there are several tests for detection of vulvovaginitis and bacterial vaginitis, most gynecology outpatient clinics in Brazil do not have the adequate equipment to perform these tests (Camargo et al., 2015). However, an alternative would be the diagnosis based on clinical evaluation by observing these infection's characteristical signs and symptoms, which can be used in virtually every health system level, as it is simple and inexpensive (Brasil, 2014; Camargo et al., 2015). However, the diagnosis based on clinical evaluation is subjective and does not identify asymptomatic infections (Ghebremichael, 2014).

Another method for detecting vulvovaginitis and bacterial vaginitis is through routine cytological tests, such as the Papanicolau test. This test is a routine procedure in periodic gynecological evaluation, being widely used in the prevention of cervical cancer and its precursor lesions. In addition to being used in screening for cervical cancer, this test enables the identification of microorganisms from the bacterial microbiota and clue cells, providing an accessible and highly useful specimen for diagnosing bacterial vaginitis, candidiasis and trichomoniasis (Camargo et al., 2015).

The Pap test is the main strategy to detect early lesions and early disease diagnosis, even before the emergence of clinical symptoms. According to the Brazilian Ministry of Health's guidelines, the Pap test should be performed on women with an active sexual life, giving priority to women aged 25 to 64 years (Inca, 2019; Brasil, 2014).

Some studies have demonstrated the importance of the Pap smear method for the diagnosis of vaginal infection causing agents (Aragão et al., 2019; Matos-Rocha, 2019; Xavier et al., 2019; Resende et al., 2019). Thus, the objective 
of this work was to determine the frequency of agents that cause vaginal infections in routine cytological exams, as well as to evaluate the characteristics of positive smears

\section{Materials and methods}

A cross-sectional, descriptive study was carried out with a quantitative approach. The research was carried out in an Anatomo-Pathological Laboratory in the city of Maceió-AL and was approved by the research ethics committee of the Centro Universitário Cesmac, under protocol number 2,711,456.

The sample was conveniently non-probabilistic, using the result of the cervical-vaginal material of sexually active women, of any age group, by the examination of the cytological smear stained using the Pap smear (Pap smear), performed between the period of 2013 to 2017.

A registration form was drawn up to obtain data, in which the characteristics were within normal limits (negative results for inflammation and / or infections), inflammations caused by non-specific agents (those that do not have an infectious process), bacterial (Gardnerella vaginalis), fungal (Candida spp), parasitic (Trichomonas vaginalis) and others (cervical-vaginal sample with absence of cellular material, menstruation due to a large amount of red blood cells, or intense infection making it impossible to see the microbiota).

As the laboratory where the research was carried out records the results of exams for gynecological infections electronically, these data were transcribed to an Excel spreadsheet to be evaluated.

\section{Results and Discussion}

In this study, 18,645 cytological reports from the years 2013 to 2017 were examined, in which the vast majority presented some inflammation, either of nonspecific origin or caused by one or more infectious agents (Table 1 ).

The Pap smear test detects alterations in cervical cells. Considered the best method to detect cervical cancer, it identifies between $80 \%$ and $95 \%$ of the disease cases, including it's initial stages, and can also identify noncancerous conditions such as infection or inflammation. It is recommended to be performed from the beginning of sexual activity (Brasil, 2014)

In the present study, 27.4\% (1254) in 2013, 10.9\% (393) in 2014, 10.6\% (371) in 2015, 15.2\% (536) in 2016 and $13.67 \%$ (469) in 2017, of patients had an oncotic cytology exam within normal limits (Graph 1), this cytology is usually constituted by Lactobacilli, the presence of vulvovaginal inflammations is frequently seen in sexually active women, $21.84 \%(4,073)$ of the inflammations were caused by some species of microorganism, $42.71 \%(7,962)$ were caused by non-specific reasons and $19.24 \%(3,587)$ by other causes (Graph 2).

Vulvovaginitis represents about $70 \%$ of the complaints of patients who seek gynecological services and are characterized by an inflammatory manifestation in the lower genital tract. In vulvovaginitis, as they sometimes show nonspecific symptoms, only laboratory exams confirmation are reliable. Early detection and treatment are fundamental as they prevent the growth of agents in the upper genital tract, which can cause pelvic inflammatory

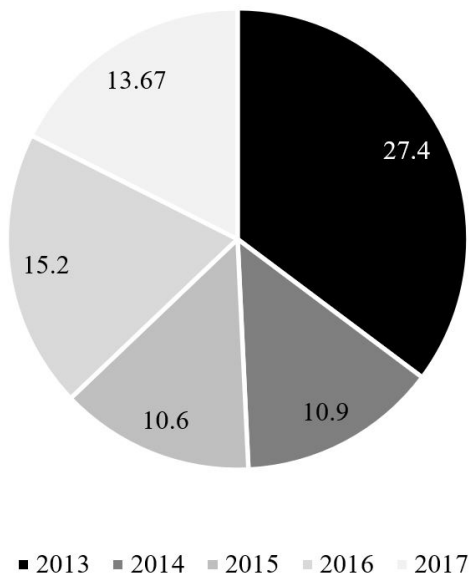

Graph 1. Results of oncotic cytology exams regarding the absence or presence of inflammation, between the years 2013 to 2017.

Table 1. Result of cytological examinations of women with infection and / or inflammation.

\begin{tabular}{|c|c|c|c|c|c|c|c|c|c|c|}
\hline Other types of diagnostics & 2013 & $\%$ & 2014 & $\%$ & 2015 & $\%$ & 2016 & $\%$ & 2017 & $\%$ \\
\hline Viral & 39 & 0.85 & 38 & 1.06 & 24 & 0.68 & 21 & 0.60 & 16 & 0.46 \\
\hline Parasitic & - & - & - & - & - & - & - & - & - & - \\
\hline Fungal & 276 & 6 & 159 & 4.4 & 170 & 4.8 & 101 & 2.86 & 108 & 3.15 \\
\hline Bacterian & 586 & 12.8 & 547 & 15.2 & 552 & 15.7 & 570 & 16.2 & 712 & 20.7 \\
\hline Parasitic+ fungal & - & - & - & - & - & - & - & - & - & - \\
\hline Bacterian + Fungal & 32 & 0,70 & 23 & 0,64 & 19 & 0,54 & 19 & 0,54 & 27 & 0,79 \\
\hline Bacterian + Parasitic & 7 & 0.15 & 9 & 0.25 & 9 & 0.26 & 4 & 0.11 & 4 & 0.12 \\
\hline Bacterian + Fungal + Parasitic & - & - & - & - & 1 & 0.03 & - & - & - & - \\
\hline Non-specific inflammation & 1708 & 37.3 & 1676 & 46.6 & 1772 & 50.4 & 1452 & 41.2 & 1354 & 39.45 \\
\hline Others & 671 & 14.7 & 751 & 20.9 & 599 & 17 & 824 & 23.4 & 742 & 21.62 \\
\hline
\end{tabular}


disease (PID), sterility, infertility, and other complications (Tabile et al., 2016).

In many gynecological services, vaginal discharge is the main complaint of women attended, followed by pruritus and vaginal odor, these symptoms are usually indicative of vulvovaginitis and can interfere in their sexual relationships. Given these considerations, prevention and early identification of vulvovaginitis can be pointed as one of the gynecological priorities in women's health care, in order to offer the appropriate treatment for each scenario (Tabile et al., 2016).

There are factors that may predispose the development of recurrent vulvovaginitis, such as vaginal candidiasis, which may be correlated with having diabetes mellitus, the use of corticosteroids, antibiotics and oral contraceptives. Apart from being pregnant, having bad hygienic habits and using inappropriate clothing, such as very tight clothes (Brandolt et al., 2017; Santos et al., 2017).

The most commonly found infectious agents in the cytopathological exams analyzed were from bacterial origin, G. vaginalis, followed by fungal, Candida spp., which can be found in the form of spores and hyphae or associated, followed by those of viral origin, mainly by human papilloma virus (HPV) and there were no cases of isolated infection by the parasite $T$. vaginalis during the five years analyzed, however this parasite is associated with bacterial infections and were not associated with fungal infections during the analyzed period (Graph 2).

Infection by these bacteria has been associated with sociocultural factors such as age, lack of adequate sexual education, educational level and occupation, which reflects in habits such as poor hygiene manners, large number of partners, early onset of a sexually active life and it is highly associated with the lack of condom use (Silva et al., 2014b).

Candida spp. was the second most frequently found infectious agent in the analyzed tests, present in $5.01 \%$. However, the simple presence of Candida spp. in vaginal content does not always equals to bearing a disease, since most women are completely asymptomatic (Gunther et al., 2014).

According to Santos et al. (2017) about 75\% of adult women have at least one case of fungal vulvovaginitis in their life, where 40 to $50 \%$ of these will experience new outbreaks, if symptomatology is present, fungal vulvovaginitis can be confirmed through tests that identify the etiological agent.

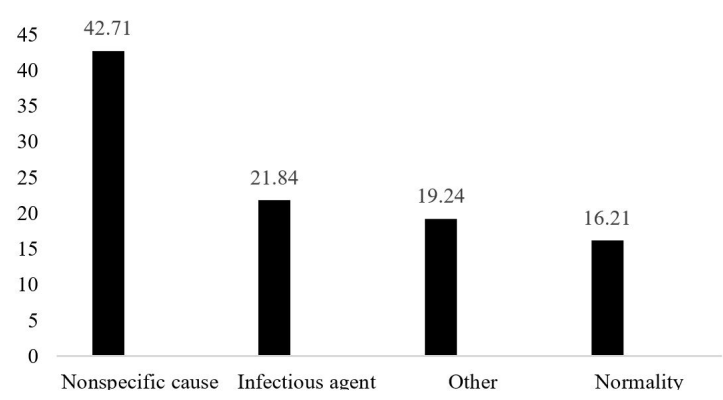

Graph 2. Result of cytological examinations of women with in the normal range, between the years 2013 to 2017.
Human papillomavirus, also known as HPV, is a virus that sets on the skin or mucosa, affecting individuals of both sexes. HPV is called the main cause of cervical cancer (CC) and is also responsible for several sexually transmitted infections, such as anal cancer, becoming the main responsible for female mortality (Alkatout et al., 2015).

According to Nakagawa et al. (2010), HPV is among the most prevalent STI, reaching about 291 million infected women worldwide, mainly in the poorest countries, being more common in sexually active young people. In Brazil, national studies have registered a prevalence profile of high-risk HPV infection similar to that of underdeveloped countries: around $17.8 \%$ to $27 \%$, with a higher prevalence in women under the age of 35, as from 35 to 65 years old, the rates remain from 12 to $15 \%$.

HPV infections may remain asymptomatic for a long time in individuals, who may be able to transmit the virus without knowing it, so routine examinations are necessary in order to detect the appearance of abnormalities, such as warts, and itching in anus and genital organs. Early diagnosis provides the tracing of early stage lesions, by using a detection method known as oncotic colpocytology or Pap smear exam (Simões, 2019).

Primary prevention of cervical cancer may decrease the risk of HPV contagion, the habit of using condoms is the main method, able to prevent about $80 \%$ of HPV infection (Herrington et al., 2015).

T. vaginalis vaginitis is an infection transmitted almost exclusively during sexual intercourse. The incubation period varies from 4 to 28 days, and the parasite can infect the vagina, urethra or bladder, causing abundant, foamy, yellowish-green or light and fetid vaginal fluid, intense vulvar itching, burning and vulvitis, dysurias and polyacuria and perineal discomfort (Meites et al., 2015).

Oncotic cytology is a great test to detect $T$. vaginalis, the fresh test is also widely used to detect it and when it is negative and trichomoniasis is suspected, culture in an appropriate medium is indicated. It is performed under anaerobic conditions, being the method of greatest sensitivity and specificity (Mielczarek and Blaszkowska, 2016).

In the present study, it was observed a high frequency of inflammations of non-specific cause, generally caused by non-living agents, which can be classified as physical or chemical factors. Physical agents can be trauma, radiation and thermal agents, while chemicals can be caused by caustic agents and anti-blast drugs. These can cause biochemical and functional modifications, altering cell morphology (Peres et al., 2015).

The diagnosis classified as others, which is seen in Graph 2, refers to a result that differs from the others, as it alludes in some cases to the absence of cellularity in the analyzed samples, another object that fits this classification is when the cytology presents a large amount of red cells preventing adequate visualization of the cells and this usually happens when the woman is tested while menstruating, in this period of the cycle it is not recommended to collect the material to be analyzed, since it can interfere with the results, however, sometimes the gynecologist performs it anyway, in addition to what was previously written, there may be results that were 
correlated with biopsy, in this case it was also classified in the category of others (Castro-Sobrinho et al., 2016).

Comparing this research with that of other authors, the majority converged and minority diverged, as was the case of Bonfanti and Gonçalves (2010), which, in the case of mixed infections, that is, associating microorganisms, presented in his research a higher prevalence of fungus + bacteria, after of fungus + parasite and lastly of bacteria + parasite, while in this research the association of microorganisms of higher prevalence was fungus + bacteria, followed by bacteria + parasite and fungus + parasite, this divergence may have possibly occurred due to the low number of analyzed samples.

Another divergence from Bonfanti's research (2010) is that his results presented $40.18 \%$ of the microbiota within normal limits and $59.82 \%$ with the microbiota altered by the presence of microorganisms. However, in the case of isolated microorganisms, the research was similar, the most common infection was caused by bacteria, then by fungi and finally by parasites, he did not search for virus infection.

According to Tabile et al. (2016), his research analyzed a sample of 200 tests in the years 2014 and 2015 and his results showed a microorganism infections incidence order similar to that of this research, in his work virus presence analysis was not performed.

In another study found, according to the research by Dall'alba and Jaskulski (2014), in which from January 2007 to January 2009, the results of cytopathological exams of 296 women were evaluated, with a total prevalence of microbiological agents examined were $73 \%$ of 293 patients, $51 \%$ of whom were bacterial vaginosis by G. vaginalis, $15 \%$ from Candida spp, and with $3 \%$ associations.

Finally, from all analyzed exams, only $16.21 \%$ were within normal range, $42.71 \%$, had an inflammation of non-specific cause, $21.84 \%$ had an infectious inflammation, therefore it is of great public and social relevance the knowing about cytological examination and its preventive performance at least once a year in order to treat infections, prevent their transmission and prevent cervical cancer.

\section{Conclusion}

In the years of 2013 to 2017, 18.645 reports were analyzed, in which a small number presented diagnoses within the normal range, in most of the reports there was an inflammation of non-specific cause and a considerable part of the reports showed an infectious inflammation.

It was identified that the most prevalent infections were those of bacterial origin caused by G. vaginalis, followed by fungal, caused by Candida ssp., Viral (HPV) and later parasitic, by T. vaginalis, the absence of this isolated infection was notorious, having a positive result only when associated with other infections in the five years analyzed.

The rates of genital infections in this study show that there is a public health problem that must be controlled, pointing to a greater need for monitoring, guidance and actions towards greater awareness in order to prevent these problems, thus oncotic cytology becomes relevant in prevention of cervix cancer, being a cost-effective test for HPV detection, in addition to identifying bacterial, fungal and / or parasitic microorganisms.

\section{References}

ALKATOUT, I., SCHUBERT, M., GARBRECHT, N., WEIGEL, M. T., JONAT, W., MUNDHENKE, C. and GÜNTHER, V., 2015. Vulvar cancer: epidemiology, clinical presentation, and management options. International Journal of Women's Health, vol. 7, pp. 305-313.

AMSEL, R., TOTTEN, P.A., SPIEGEL, C.A., CHEN, K.C., ESCHENBACH, D. and HOLMES, K.K., 1983. Nonspecific vaginitis. Diagnostic criteria and microbial and epidemiologic associations. The American Journal of Medicine, vol. 74, no. 1, pp. 14-22. http:// dx.doi.org/10.1016/0002-9343(83)91112-9. PMid:6600371.

ARAGÃO, F.B.A., SANTOS, G.R.B., LOBÃO, W.J.M., OLIVEIRA, A.P., MONTEIRO, S.G., SANTOS, L.M., REIS, A.D., NETO, M.S. and BATISTA, J.E., 2019. Associação do perfil microbiológico com alterações citológicas em mulheres quilombolas atendidas nas unidades básicas de saúde. Medicina, vol. 52, no. 4, pp. 313-320. http://dx.doi.org/10.11606/issn.2176-7262.v52i4p311-318.

BONFANTI, G. and GONÇALVES, T. L., 2010. Prevalência de Gardnerella vaginalis, Candida spp. e Trichomonas vaginalis em exames citopatológicos de gestantes atendidas no hospital universitário de Santa Maria - RS. Revista Saúde, vol. 36, no. 1, pp. 37-46. http://dx.doi.org/10.5902/223658342343.

BRANDOLT, T.M., KLAFKE, G.B., GONÇALVES, C.V., BITENCOURT, L.R., MARTINEZ, A.M., MENDES, J.F., MEIRELES, M.C. and XAVIER, M.O., 2017. Prevalence of Candida spp. in cervical-vaginal samples and the in vitro susceptibility of isolates. Brazilian Journal of Microbiology, vol. 48, no. 1, pp. 145-150. http://dx.doi. org/10.1016/j.bjm.2016.09.006. PMid:27756539.

BRASIL MINISTÉRIO DA SAÚDE, SECRETARIA DE VIGILÂNCIA EM SAÚDE. DEPARTAMENTO DE VIGILÂNCIA EPIDEMIOLÓGICA. COORDENAÇÃO GERAL DO PROGRAMA NACIONAL DE IMUNIZAÇÕES, 2014. Informe Técnico sobre a Vacina Papilomavírus Humano - HPV na Atenção Básica. Brasília, DF.

CAMARGO, K.C., ALVES, R.R.F., BAYLÃO, L.A., RIBEIRO, A.A., ARAUJO, N.L.A.S., TAVARES, S.B.N. and SANTOS, S.H.R., 2015. Secreção vaginal anormal: Sensibilidade, especificidade e concordância entre o diagnóstico clínico e citológico. Revista Brasileira de Ginecologia e Obstetrícia, vol. 37, no. 5, pp. 222-228. http:// dx.doi.org/10.1590/SO100-720320150005183. PMid:26107573.

CARTWRIGHT, C.P., LEMBKE, B.D., RAMACHANDRAN, K., BODY, B.A., NYE, M.B., RIVERS, C.A. and SCHWEBKE, J.R., 2013. Comparison of nucleic acid amplification assays with BD affirm VPII for diagnosis of vaginitis in symptomatic women. Journal of Clinical Microbiology, vol. 51, no. 11, pp. 3694-3699. http://dx.doi. org/10.1128/JCM.01537-13. PMid:23985917.

CASTRO-SOBRINHO, J.M., RABELO-SANTOS, S.H., FUGUEIREDOALVES, R.R., DERCHAIN, S., SARIAN, L.O., PITTA, D.R., CAMPOS, E.A. and ZEFERINO, L.C., 2016. Bacterial vaginosis and inflammatory response showed association with severity of cervical neoplasia in HPV-positive women. Diagnostic Cytopathology, vol. 44, no. 2, pp. 80-86. http://dx.doi.org/10.1002/dc.23388. PMid:26644228.

DALL'ALBA, M.P. and JASKULSKI, M.R., 2014. Prevalência de vaginoses bacterianas causadas por Gardnerella vaginalis, em um laboratório de análises clínicas na cidade de Santo Expedito do Sul, RS. Perspectiva, vol. 38, pp. 91-99.

FERRAZ, R.R., NEVES, E.R.M., ARCARI, D.P., BARNABE, A.S. and FORNARI, J.V., 2014. Métodos de diagnóstico da tricomoníase: comparação do método da microscopia de montagem molhada com o método de cultura convencional. Saúde em Foco, vol. 3, no. 1, pp. 40-43.

GALLO, G. E. and FABIÃO, C. D., 2016. Prevalência de Vaginose Bacteriana em Mulheres Sexualmente Ativas Atendidas em Unidade Básica de Saúde de Pelotas, RS. Revista Ensaios e Ciências, vol.20, n. 3, pp. 200-202. https://doi.org/10.17921/14156938.2016v20n3p172-174. 
GHEBREMICHAEL, M., 2014. The syndromic versus laboratory diagnosis of sexually transmitted infections in resourcelimited settings. ISRNAIDS, vol. 2014, pp. 103452. http://dx.doi. org/10.1155/2014/103452. PMid:24729919.

GUNTHER, L.S.A., MARTINS, H.P.R., GIMENES, F., ABREU, A.L.P., CONSOLARO, M.E.L. and SVIDZINSKI, T.I.E., 2014. Prevalence of Candida albicans and non-albicans isolates from vaginal secretions: comparative evaluation of colonization, vaginal candidiasis and recurrent vaginal candidiasis in diabetic and non-diabetic women. São Paulo Medical Journal, vol. 132, no. 2, pp. 116-120. http:// dx.doi.org/10.1590/1516-3180.2014.1322640. PMid:24714993.

GREENBAUM, S., GREENBAUM, G., MORAN-GILAD, J. and WEINTRAUB, A., 2019. Ecological dynamics of the vaginal microbiome in relation to health and disease. American Journal of Obstetrics and Gynecology, vol. 220, no. 4, pp. 324-335. http:// dx.doi.org/10.1016/j.ajog.2018.11.1089 PMid:30447213.

HERRINGTON, C., COATES, P. and DUPREX, W., 2015. Viruses and disease: emerging concepts for prevention, diagnosis and treatment. The Journal of Pathology, vol. 235, no. 2, pp. 149-152. http://dx.doi.org/10.1002/path.4476. PMid:25366544.

INSTITUTO DE CÂNCER JOSÉ ALENCAR GOMES DA SILVA - INCA, 2019 [viewed 4 Apr. 2019]. Estatística de câncer, número de casos [online]. Available from: https://www.inca.gov.br/ numeros-de-cancer

KLEBANOFF, S.L. and COOMBS, R.W., 1991. Virucidal effect of lactobacillus acidophilus on human immunodeficiency virus type-1: possible role in heterosexual transmission. The Journal of Experimental Medicine, vol. 174, no. 1, pp. 289-292. http:// dx.doi.org/10.1084/jem.174.1.289. PMid:1647436.

LACERDA, W.C., VALE, J.S., LACERDA, W.C. and CARDOSO, J.L.M.S., 2015. Infecção urinária em mulheres: revisão da literatura. Saúde em Foco, vol. 7, no. 1, pp. 282-295.

LEDGER, W.J. and WITKIN, S.S., 2016. Vulvovaginal infections. 2nd ed. Boca Raton, FL: CRC Press Taylor \& Francis Group. Chapter 2 - Vaginal immunology, pp. 7-12. http://dx.doi. org/10.1201/b19507.

LIMA, M.O., SAMPAIO, M.G.V. and SANTOS, B.S., 2017. A importância do diagnóstico precoce da tricomoníase e as principais técnicas utilizadas na confirmação da doença. Revista Expressão Católica Saúde, vol. 2, no. 2. http://dx.doi.org/10.25191/recs.v2i2.2177.

LINHARES, I.M., AMARAL, R.L., ROBIAL, R. and ELEUTÉRIO JUNIOR, J., 2018. Vaginites e Vaginoses. São Paulo: FEBRASGO. Protocolo FEBRASGO - Ginecologia, no 24, Comissão Nacional Especializada em Doenças Infectocontagiosas.

LOWE, N.K., NEAL, J.L. and RYAN-WENGER, N.A., 2009. Accuracy of the clinical diagnosis of vaginitis compared to a DNA probe laboratory standard. Obstetrics and Gynecology, vol. 113, no. 1, pp. 89-95. http://dx.doi.org/10.1097/AOG.0b013e3181909f63. PMid:19104364.

MACHADO, E.R. and SOUZA, L.P., 2012. Tricomoníase: Assistência de enfermagem na prevenção e controle. Ensaios e Ciência: Ciências Biológicas, Agrárias e da Saúde, vol. 16, no. 4, pp. 229-243.

MATOS-ROCHA, T.J., 2019. Frequência de Trichomonas vaginalis nos exames citopatológicos de mulheres atendidas em um laboratório privado do município de Maceió-AL. Scientia Vitae, vol. 8, no. 25, pp. 12-18.

MEITES, E., GAYDOS, C.A., HOBBS, M.M., KISSINGER, P., NYIRJESY, P., SCHWEBKE, J.R., SECOR, W.E., SOBEL, J.D. and WORKOWSKI, K.A., 2015. A review of evidence-based care of Symptomatic Trichomoniasis and Asymptomatic Trichomonas vaginalis Infections. Clinical infectious diseases, vol. 8, pp. S837-S848. http://dx.doi.org/10.1093/cid/civ738. PMid:26602621.
MIELCZAREK, E. and BLASZKOWSKA, J., 2016. Trichomonas vaginalis: pathogenicity and potential role in human reproductive failure. Infection, vol. 44, no. 4, pp. 447-458. http://dx.doi.org/10.1007/ s15010-015-0860-0. PMid:26546373.

MOSCA, V.A.B. and MENDONÇA, P.S.B., 2016. Tricomoníase e outras vulvovaginites em mulheres atendidas em unidades básicas de saúde de mandaguari. Revista UNINGÁ Review, vol. 28, no. 2, pp. 47-51.

NAKAGAWA, J.T.T., SCHIRMER, J. and BARBIERI, M., 2010. Vírus HPV e câncer de colo de útero. Revista Brasileira de Enfermagem, vol. 63, no. 2, pp. 307-311. http://dx.doi.org/10.1590/S003471672010000200021. PMid:20521005.

NASIOUDIS, D., LINHARES, I.M., LEDGER, W.J. and WITKIN, S.S., 2017. Bacterial vaginosis: A critical analysis of current knowledge. BJOG, vol. 124, no. 1, pp. 61-69. http://dx.doi.org/10.1111/14710528.14209. PMid:27396541.

NIEVAS, Y.T., VASHISHT, A.A., CORVI, M.M., METZ, S., JOHNSON, P.J., WOHLSCHLEGEL, J.A. and DE MIGUEL, N., 2018. Protein palmitoylation plays an important role in Trichomonas vaginalis adherence. Rev Papers, vol. 18, no. 3, pp. 10-27. http://dx.doi. org/10.1074/mcp.RA117.000018.

PERES, A.L., CAMAROTTI, J.R.S.L., CARTAXO, M., ALENCAR, N., STOCCO, R.C., BEÇAK, W., PONTES FILHO, N.T., ARAÚJO, R.F.F., LIMA FILHO, J.L. and MARTINS, D.G.B., 2015. Molecular analysis and conventional cytology: association between HPV and bacterial vaginosis in the cervical abnormalities of a Brazilian population. Genetics and Molecular Research, vol. 14, no. 3, pp. 9497-9505. http://dx.doi.org/10.4238/2015. August.14.13. PMid:26345883.

RAUGUST, T. M. and DUARTE, A. C. R., 2013. Aspectos clínicos, epidemiológico e diagnóstico citológico de Candida sp, Gardnerella vaginalis e Trichomonas vaginalis. Revista Eletrônica de Análises Clínicas, vol. 1, no. 1, pp. 2229-2241.

RESENDE, A. F., SANTOS, R. W. F., GASPAR, L. M. A. C. and ALMEIDA, P. O.S., 2019. Prevalência de vaginoses bacterianas em pacientes que realizaram bacterioscopia de secreção vaginal. Revista de Ciências Médicas e Biológicas, vol. 18, no. 2, pp. 190-193. http:// dx.doi.org/10.9771/cmbio.v18i2.29698.

SANTOS, L.P.L., GONÇALVES, J.S., OLIVEIRA, P.C. and ALMEIDA, M.M.C., 2017. Prevalência de vulvovaginites em mulheres atendidas em uma unidade de saúde. Revista Temas em Saúde, vol. 17, no. 2, pp. 260-269.

SILVA, N. G., CAVALHEIRO, M. D., TASHIMA, C. M. and NETO, J. T., 2014a. Ocorrência de Infecções Ginecológicas em gestantes. Revista Odontologia, vol. 14, no. 4, pp. 225-237.

SILVA, N.C., ROCHA, T.A.H., RODRIGUES, R.B. and BARBOSA, A.C.Q., 2014b. Equidade na atenção primária à saúde da mulher: uma análise do Brasil e suas regiões. Revista Baiana de Saúde Pública, vol. 38, no. 2, pp. 243-265. http://dx.doi.org/10.22278/23182660.2014.v38.n2.a525.

SIMÕES, L.P., 2019. Vírus HPV e o desenvolvimento de câncer de colo de útero -uma revisão bibliográfica. Rev. UNINGÁ, vol. 56, no. 1, pp. 98-107.

TABILE, P.M., LUCENA, H., CHAVES, J., FISCHBORN, J. and JUCÁ, R.B., 2016. Características clínicas, prevalência e diagnóstico de vulvovaginites em ambulatórios do interior do Rio Grande do Sul. Journal of Health and Biological Sciences, vol. 4, pp. 160-165. http://dx.doi.org/10.12662/2317-3076jhbs.v4i3.657. p160-165.2016.

XAVIER, C.M., IMBASSAHY FILHO, M., ARAÚJO, J.T.T. and OLIVEIRA, A.V., 2019. Frequência de Trichomonas vaginalis e Gardnerella vaginalis em exames colpocitológicos realizados em uma rede de laboratórios privados no município de João Pessoa - PB. Revista de Ciências da Saúde Nova Esperança, vol. 7, no. 1, pp. 47-52. http://dx.doi.org/10.17695/issn.2317-7160.v17n1a2019p47-52. 